public complaint. The consumer, he said, is entitled to demand that such industries avoid extravagant administration, attain a high degree of efficiency, pass to the consumer a substantial share of the results of higher productivity and have sufficient regard to the legitimate wishes of the consumer in matters of quality and variety.

Most of Mr. Morrison's address was devoted to an outline of the general organisation of the various public boards controlling certain industries in Britain, in which he stressed particularly the safeguards provided for the interest of the consumer. We have to rely on the various boards, Mr. Morrison said, to hold the balance fairly between consumer and worker, and he concluded that the consumer would be primarily dependent for a fair and reasonable level of price on the efficiency of the boards and their ability to keep both management and workers 'on their toes'. Such public boards should provide a reasonable safeguard against gross discrimination between consumers, but the address contained little evidence that the conditions Mr. Morrison specified are, in fact, being observed. It cannot now be seriously contended that even the Post Office passes on to the public the advantages in speed and efficiency which technical improvements have made possible, and the difficulties experienced in raising questions in the House of Commons regarding the public boards suggests that new means must be sought of making them sensitive to public opinion.

\section{Australian Council for Scientific and Industrial Research}

Desprte grave misrepresentation of its motives, the Executive Committee of the Australian Council for Scientific and Industrial Research appears to have convinced the Commonwealth Government that scientific work for war purposes should be conducted under the Ministry of Supply or the Ministry of Defence rather than under the Council. The contention is that the conditions of secrecy and military security essential nowadays for war-work will require an atmosphere in which the normal activities of the Council on behalf of primary and secondary industry simply cannot flourish. The Council has for twentytwo years operated under an Act, originated by Viscount Bruce, giving it a high degree of freedom and independence; for many reasons it is believed that, in existing conditions, the two contrasting lines of work cannot be effectively controlled by the one body.

In providing for the transfer to another Commonwealth agency, under public service board control, of the small amount of work bearing on defence at present conducted in the laboratories of the Council for Scientific and Industrial Research, a Bill now before Parliament unfortunately goes further and opens the way for subjecting any or all of the Council's activities to public service board procedure and regulations. Strong exception is being taken by scientific men and societies in Australia to this action, which is regarded as a serious threat to the spirit and successful working which have characterized the Council for Scientific and Industrial Research in the Fast.

\section{Australian Journal of Scientific Research}

A NEW periodical of high standard, the Australian Journal of Scientific Research, has recently been launched by the Australian Council of Scientific and Industrial Research, Melbourne, in collaboration with the Australian National Research Council (see Nature, August 7, 1948, p. 210). It is being issued quarterly in two series, Series A (Physical Sciences) and Series B (Biological Sciences), the price of each being $7 s .6 d$. The editor and chairman of the editorial board is Dr. N. S. Noble, and the other members of the board are Profs. W. J. Dakin, E. J. Hartung, L. H. Martin and J. G. Wood.

The first number (March 1948) of Series A contains seven papers on physical, chemical, metallurgical and meteorological subjects, indicating the variety of researches undertaken or sponsored by the Australian Council of Scientific and Industrial Research. These include: an analytical treatment, by G. H. Godfrey, of the distribution of light intensity in the Fraunhofer diffraction pattern of continuous light sources, in which attention is directed to certain diffraction effects which have not been previously recorded but which are in agreement with the theory; a study, by V. D. Hopper and A. M. Grant, of the effect of a horizontal wall on the motion of oil drops, of radii 5-15 $\mu$, falling in air, in order that the corrections to be applied in the precise determination of the electronic charge by the oil-drop method may be accurately made; observations on a strong variable source of radio frequency energy in the constellation of Cygnus ; a microscopic and X-ray examination of the deformation or recrystallization of a duplex brass; and the testing of molecular layers of the silicones on various metal surfaces for their boundary lubricating properties.

\section{German Scientific and Technical Periodicals}

THE Foreign Office of Great Britain has recently compiled a list of more than three hundred German scientific and technical periodicals which have resumed publication. The list is divided into the following sections : agriculture and forestry ; mathe. matics, physics and chemistry; medicine; natural science; and technology and industry. Very short notes, including the price where listed, are given with each periodical. Inquiries regarding the list should be made to the Foreign Office (German Section), Room 211, King Charles Street, London, S.W.1.

\section{Financial Aid for Delegates at Conferences}

THE British Council has a small fund for the assistance of overseas delegates wishing to attend national or international conferences held in the United Kingdom on scientific subjects including agriculture, engineering and medicine. Except in special circumstances, fares to and from the United Kingdom will not be paid, and the grants are mainly designed to cover subsistence of the delegate for the duration of the conference up to a period of two weeks. Conveners of conferences to be held during the period April 1, 1949-March 31, 1950, should apply to the Director, Visitors Department, British Council, 3 Hanover Street, London, W.1, giving full details including the number of delegates requiring assistance and their nationalities. Such information should be lodged preferably not later than January 15, and replies will be made by the end of February.

\section{World Federation for Mental Health}

THe World Federation for Mental Health, formed at the time of the international congress in London last August, has now been officially recognized for consultative purposes by the two United Nations 